\title{
MENINGKATKAN MOTIVASI BELAJAR SISWA PADA MATERI PERDAGANGAN INTERNASIONAL MELALUI MODEL MAKE A MATCH DI KELAS IX C SMP LAB UM
}

\author{
Yudha Intan Kartika Buana ${ }^{1 *}$, Agus Purnomo ${ }^{2}$
}

Diterima 2 Februari 2019, Dipublikasikan 30 April 2019

(CPenulis (2019)

\begin{abstract}
Motivation is identified as one of the important factors in constructing knowledge. This process is a vital part of constructivism learning. The purpose of this article is to examine the motivational strength of its application in Classroom Action Research (CAR). The results show that there is very little attention in motivation. In fact, if educators can increase motivation it will have an impact on the construction stage of knowledge in students. Therefore there are at least 3 components that need to be considered related to motivation in constructivism learning, namely: (1) learning challenges, (2) dual goals, and (3) class climate.
\end{abstract}

Keywords

Motivation, make a match

\section{PENDAHULUAN}

Motivasi belajar siswa kelas IX C pada mata pelajaran IPS tergolong cukup rendah. Banyak faktor yang menyebabkannya, beberapa di antaranya adalah; waktu belajar IPS yang cenderung pada akhir jadwal, konten IPS yang cakupannya banyak sekali tanpa ada waktu untuk menjelaskan dengan hal konkret, dan keberagaman aspek jawaban pada bidang sosial. Oleh karena itu perlu ada solusi yang tepat untuk mengatasi permasalahan ini, salah satunya dengan model pembelajaran yang menyenangkan.

Model pembelajaran make a macth merupakan salah satu solusi yang dapat digunakan untuk meningkatkan motivasi belajar siswa. Model make a match dapat meningkatkan motivasi belajar siswa secara signifikan (Harminingsih, 2015; Sutarniyati, 2016; Widyaningrum, 2015). Model make a match dapat meningkatkan motivasi belajar karena siswa secara aktif terlibat dalam pembelajaran melalui kelompok kecil. Jumlah anggota kelompok yang lebih sedikit akan memungkinkan mereka akan makin banyak terlibat dan mau untuk mengikuti kegiatan belajar. Atas dasar rasional tersebut maka tujuan dari artikel ini untuk mengungkapkan keunggulan model make a match dalam meningkatkan motivasi belajar siswa pada mata pelajaran IPS.

\section{METODE}

Penelitian ini merupakan Penelitian Tindakan Kelas (Classroom Action Research) dengan bentuk kolaborasi. Idealnya dilakukan secara berpasangan antara pihak yang melakukan tindakan dan pihak yang mengamati proses jalannya tindakan (Arikunto \& Suhardjono,

$1 \quad$ SMP Lab Universitas Negeri Malang

yudha.intan.wa2an@gmail.com

2 Program Studi Pendidikan IPS Universitas Negeri Malang 
2010). Cara ini dikatakan ideal karena adanya upaya untuk mengurangi unsur subjektifitas pengamat serta mutu yang dilakukan. Penelitian kolaborasi ini sangat disarankan kepada guru yang belum pernah atau masih jarang melakukan penelitian. Oleh karena itu, peneliti melakukan penelitian dengan berkolaborasi dengan guru sebanyak dua siklus. Hal ini dimaksudkan untuk mengurangi tingkat subjektifitas peneliti. Apabila sudah diketahui letak keberhasilan dan hambatan dari tindakan yang baru dilaksanakan dalam satu siklus, guru pelaksana (bersama peneliti pengamat) menentukan rancangan untuk siklus kedua. Hal ini dilakukan untuk meyakinkan atau menguatkan hasil dari siklus pertama.

Pada dasarnya penelitian ini merujuk pada permasalahan yang ada di kelas. Penelitian ini juga bisa berdasarkan permasalahan yang dirasakan langsung oleh guru yang bersangkutan (Arikunto, et al., 2012). Jenis penelitian tersebut sangat bermanfaat sebagai upaya untuk memperbaiki proses pembelajaran di kelas. Penelitian tindakan ini juga bertujuan untuk menemukan fakta dan pemecahan masalah dalam situasi sosial untuk meningkatkan kualitas tindakan yang dilakukan di dalamnya (Suwarsih, 2007). Dari pemaparan ahli di atas dapat disimpulkan bahwa penelitian tindakan kelas adalah penelitian yang dilakukan untuk menemukan fakta dan cara pemecahan masalah di lingkungan sosial masyarakat atau sebuah kelompok dan hasil dari penelitian tersebut dapat langsung dirasakan manfaatnya oleh masyarakat. Dalam penelitian ini, peneliti menggunakan pendekatan kualitatif dan kuantitatif. Peneliti terlibat secara langsung dari tahap perencanaan hingga selanjutnya peneliti memantau, mencatat dan mengumpulkan data. Data yang sudah terkumpul kemudian akan dianalisis dan disusun menjadi sebuah laporan hasil penelitian. Dalam penelitian ini akan dilakukan dengan dua tahap, yaitu tahap pendahuluan atau refleksi awal dan juga tahap pelaksanaan tindakan.

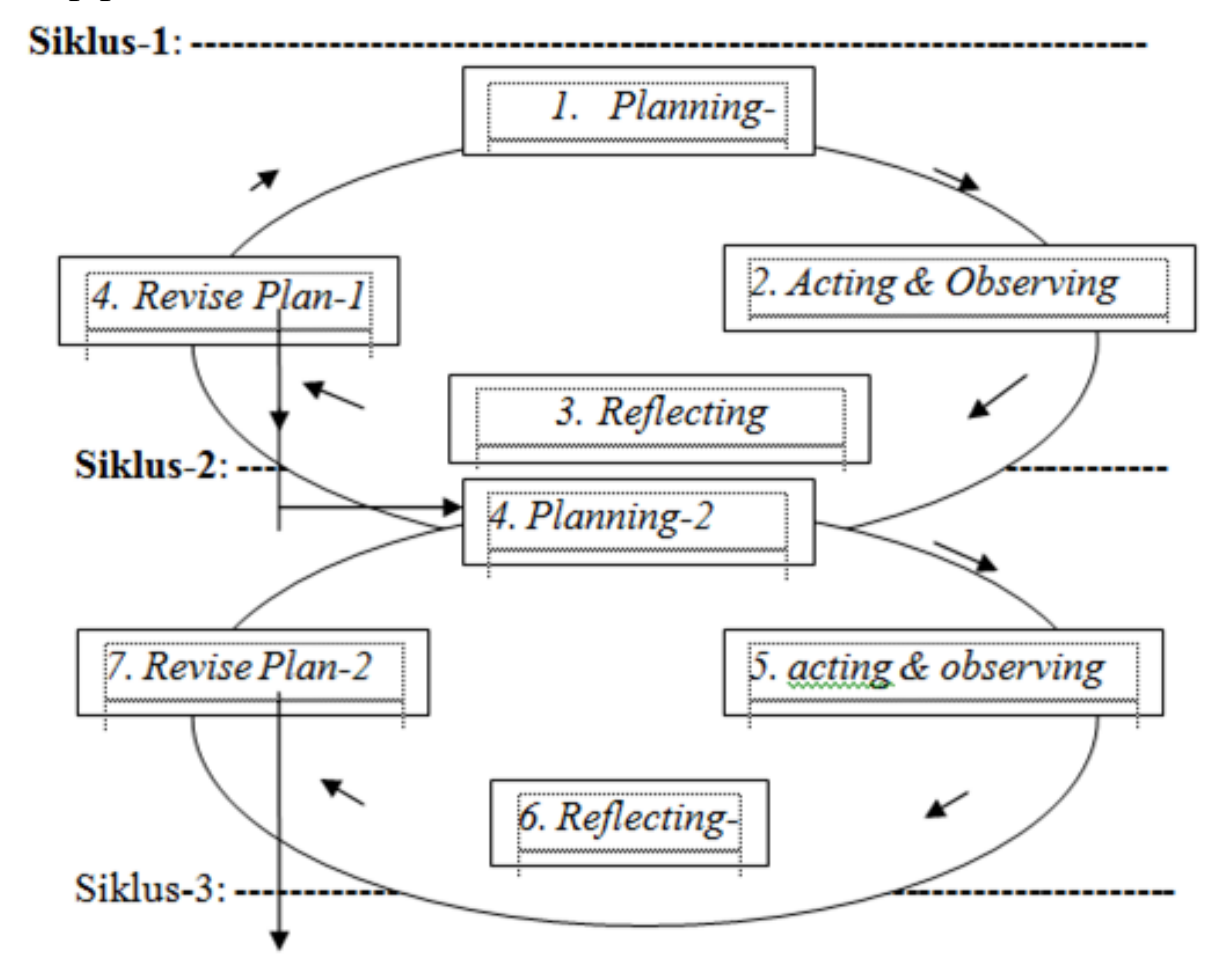

Gambar 1 Siklus PTK (Arikunto \& Suhardjono, 2010) 
Pengumpulan data menggunakan teknik observasi dengan bantuan observer yang menggunakan lembar pengamatan. Hasil pengamatan kemudian dianalisis menggunakan tabulasi tunggal menelaah pola sebaran data yang ada. Pola sebaran data tersebut kemudian yang menjadi dasar utama pembahasan hasil pelaksanaan PTK.

\section{HASIL DAN PEMBAHASAN}

Motivasi telah didefinisikan sebagai keadaan internal yang mengaktifkan, memandu, dan memelihara perilaku (Green, 2002). Dari sudut pandang pendidikan, istilah motivasi dapat berlaku untuk setiap proses yang mengaktifkan dan mempertahankan perilaku belajar. Sebagian besar penelitian di bidang ini telah dilakukan baik dari perspektif behavioris atau perspektif kognitif sosial. Sebagian besar penelitian terbaru telah mengadopsi pandangan kognitif sosial. Berbeda dengan model lama di mana motivasi diasumsikan menjadi ciri kepribadian relatif stabil, pandangan kognitif sosial memiliki keyakinan bahwa motivasi dapat secara signifikan dipengaruhi oleh kondisi kelas yang dinamis (Pintrich \& Schunk, 1996).

Pertama, motivasi telah digambarkan dalam bentuk ekstrinsik dan intrinsik. Motivasi intrinsik mengacu melakukan sesuatu karena tertarik atau senang, dan motivasi ekstrinsik mengacu melakukan sesuatu karena mengharapkan penghargaan atas hasil yang dilakukan (Deci, et al., 2001). Oleh karena itu motivasi ekstrinsik berfokus pada faktor-faktor eksternal individu dan tugas, seperti penghargaan, pujian, hak istimewa, atau perhatian. Misalnya, guru dapat memberikan siswa stiker untuk pekerjaan yang sudah selesai. Di sisi lain, motivasi intrinsik secara langsung berhubungan dengan tugas yang sedang dilakukan. Menurut teori motivasi intrinsik, seseorang merasa senang ketika belajar sesuatu yang baru atau berhasil dalam tugas yang menantang. Hal ini menciptakan perasaan percaya diri dan penguasaan yang memperkuat diri, sehingga siswa akan lebih cenderung untuk terlibat dalam kegiatan pembelajaran di masa mendatang. Motivasi intrinsik umumnya dianggap lebih efektif dalam mempromosikan belajar dan prestasi (Deci, et al., 2001).

Motivasi intrinsik dapat ditingkatkan di dalam kelas dengan menyediakan tantangan, rasa ingin tahu, fantasi, dan kontrol (Lepper \& Drake, 1996). Tantangan mengacu pada tingkat kesulitan yang akan memungkinkan peserta didik untuk mengalami rasa penguasaan dan kompetensi ketika mereka berhasil. Tingkat tantangan yang disajikan bisa bervariasi berupa tugas dari peserta didik untuk peserta didik sesuai dengan kemampuan mereka (Eskasasnanda \& Purnomo, 2018), perbedaan ini dapat dikompensasi dengan memungkinkan mereka untuk bekerja pada kecepatan mereka sendiri, atau siapa yang selesai lebih awal (Stipek, 2002). Motivasi intrinsik juga dapat ditingkatkan dengan kegiatan yang memanfaatkan imajinasi dan fantasi, karena ini memungkinkan mereka untuk melangkah keluar dari kehidupan nyata dan membuat perbandingan dengan kehidupan nyata.

Pemberian tugas juga mampu meningkatkan motivasi belajar peserta didik. Tugas kelas harus bermakna dan relevan dengan kehidupan peserta didik, sehingga ada manfaat yang dirasakan dalam memahami konten (Ames, 1992). Akhir pembelajaran, mereka harus diberikan umpan balik dan pujian untuk keberhasilan atau usaha mereka dalam menguasai pengetahuan baru tersebut (Xiang, et al., 2003). Perbandingan sosial dari hasil dan umpan balik harus dihindari, dan sebaliknya harus ada pengakuan pribadi untuk usaha mereka. 


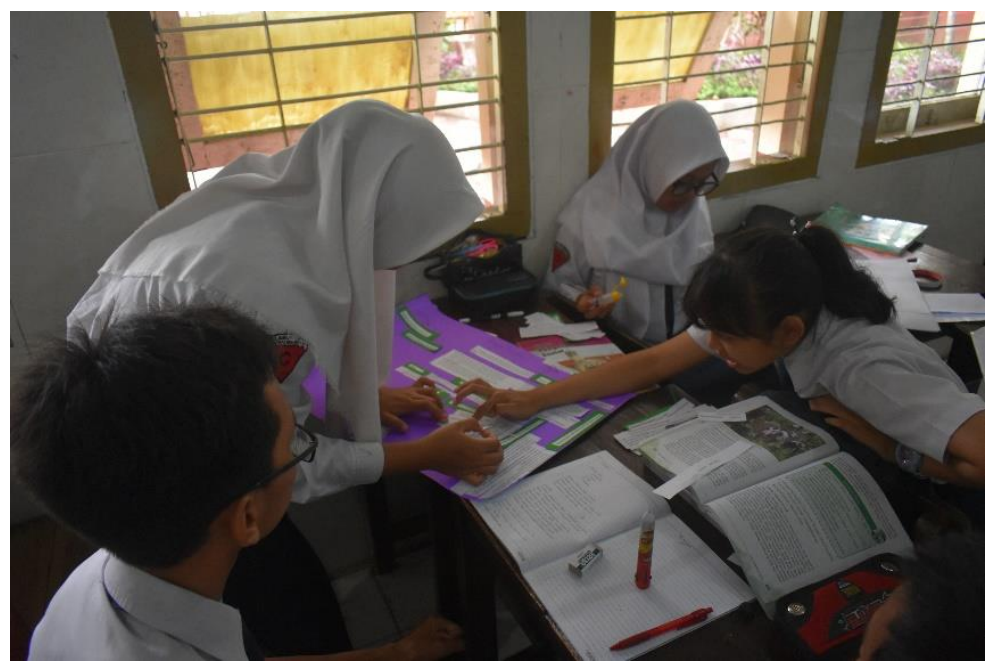

Gambar 2 Kegiatan belajar mandiri dalam kelompok

Nilai harapan berkaitan dengan penilaian siswa tentang harapan mereka dari keberhasilan dan kegunaan konten (Wigfield \& Eccles, 2000). Harapan adalah keyakinan peserta didik tentang kemampuan dan peluang keberhasilan dalam melaksanakan tugas tertentu mereka, sedangkan nilai tugas mengacu pada nilai yang dirasakan dari material yang akan dipelajari. Tiga jenis nilai telah diidentifikasi. Nilai Tertinggi adalah sejauh mana tugas berkaitan dengan citra diri. Misalnya, peserta didik yang menganggap dirinya pandai dalam bidang IPS ingin mengkonfirmasi dengan belajar IPS dengan baik. Nilai Utility menyangkut kegunaan tugas. Misalnya, belajar IPS dapat membantu untuk masuk program ilmu sosial di universitas. Nilai Intrinsik mengacu pada kenikmatan yang melekat dalam tugas, dan sangat erat kaitannya dengan konstruksi motivasi intrinsik.

Jika motivasi merupakan prasyarat untuk pembangunan pengetahuan, maka pendidik harus mencoba untuk mempromosikan sebanyak mungkin motivasi positif, dan untuk melakukan hal ini mereka idealnya harus memanfaatkan berbagai strategi motivasi. Berikut ini adalah ringkasan strategi untuk konstruksi motivasi dijelaskan pada bagian sebelumnya.

Dalam rangka meningkatkan motivasi peserta didik, maka pendidik harus melakukan:

1. Tantangan siswa dengan menetapkan tugas pada tingkat kesulitan yang bertahap dari sangat mudah hingga sangat sulit;

2. Menggunakan pengalaman pribadi peserta didik untuk membangkitkan rasa ingin tahu;

3. Menggunakan fantasi/imajinasi sebagai strategi untuk memacu daya pikir peserta didik melampaui kondisi saat ini;

4. Meningkatkan kebermaknaan isi dan tugas dengan mengaitkannya dengan kehidupan sehari-hari;

5. Menggunakan berbagai jenis kegiatan dan tugas-tugas;

6. Melibatkan peserta didik untuk menjadi peserta aktif dalam pembelajaran;

7. Memungkinkan peserta didik untuk memilih rekan kerja, kegiatan dan format tugas secara mandiri untuk menciptakan suasana yang demokratis;

8. Memungkinkan siswa untuk bekerja secara individual atau bersama-sama dalam situasi yang tidak mendorong persaingan, tujuannya adalah untuk mutual learning;

9. Memberikan umpan balik penilaian, dan menggunakan pujian yang memberikan penghargaan usaha dan perbaikan (ini harus diberikan secara pribadi, untuk menghindari perbandingan sosial); 
10. Mendukung, meyakinkan, dan penuh perhatian kepada peserta didik.

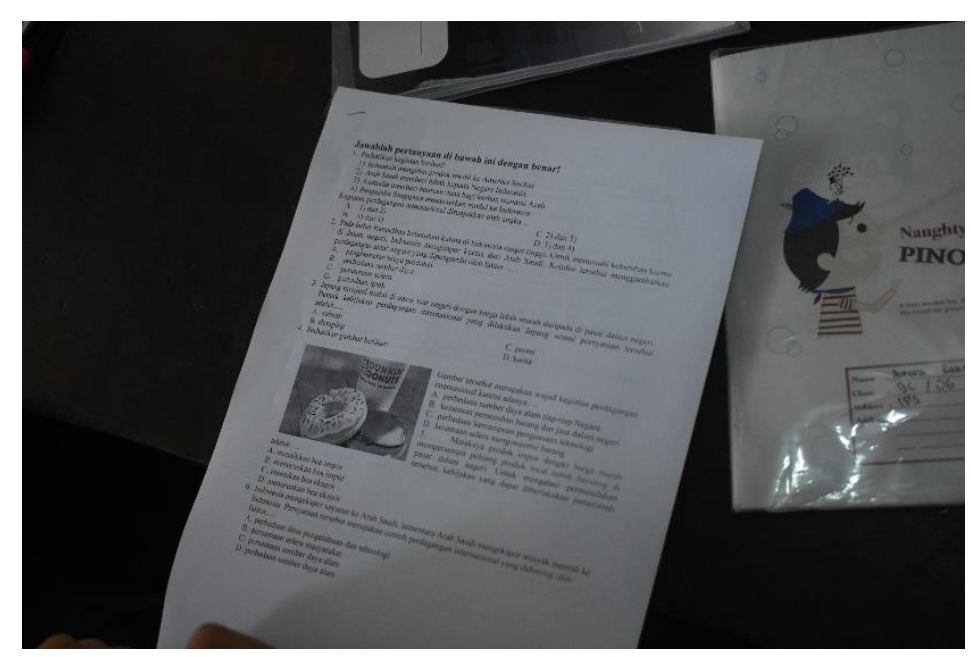

Gambar 3 Tantangan kegiatan belajar lanjutan

Tentu saja, beberapa peserta didik masih termotivasi bahkan jika pendidik tidak memanfaatkan strategi ini. mereka tersebut mungkin sudah memiliki kepentingan individu tinggi atau tujuan pembelajaran yang dikembangkan dengan baik. Namun, penelitian menunjukkan bahwa, selama sekolah menengah atas dan perguruan tinggi, motivasi seperti itu sangat sedikit. Hal ini umumnya karena ada penurunan yang kuat dalam motivasi selama sekolah menengah atas (Aderman \& Maehr, 1994). Beberapa alasan yang dapat menjelaskan adalah karena beban belajar yang terlalu banyak. Setelah mereka seharian menghabiskan tenaga dan perhatian di kelas. Sepulang sekolah masih harus mengerjakan tugas tambahan yang terkadang melupakan esensi mengaitkan konten dengan kehidupan mereka sehari-hari. Kurikulum kita lebih mengedepankan mengetahui sedikit tentang banyak hal dari pada mengetahui banyak tentang sedikit hal. Artinya peserta didik tidak bisa fokus pada satu bidang yang diminatinya.

Terlepas dari kenyataan itu, dapat disimpulkan bahwa ada berbagai strategi motivasi yang dapat diintegrasikan ke dalam kelas. Bagian berikutnya akan menjelaskan beberapa model pembelajaran konstruktivisme dan akan menentukan sejauh mana jenis strategi tersebut dimasukkan di dalamnya.

\section{KESIMPULAN}

Model pembelajaran make a match terbukti mampu untuk meningkatkan motivasi belajar peserta didik. Hal ini dikarenakan model ini mampu menstimulasi tantangan yang bertahap sehingga tidak ada kesan monoton selama pembelajaran. Tantangan bertahap dapat diberikan dalam bentuk penugasan atau evaluasi hasil kerja dari kegiatan belajar mandiri secara berkelompok. Yang perlu menjadi catatan adalah seyogyanya tantangan yang diberikan memiliki sifat kontekstual sehingga mereka akan memiliki pola pikir bahwa pengetahuan ini akan bermanfaat dalam kehidupan mereka sehingga secara langsung mereka akan mau untuk terlibat langsung dalam pembelajaran. 


\section{DAFTAR PUSTAKA}

Aderman \& Maehr, 1994. Motivation and schooling in the middle grades. Review of Educational Research, 64(2), pp. 287-309.

Ames, 1992. Classrooms: Goals, structures, and student motivation. Journal of Educational Psychology, 84(3), pp. 261-271.

Arikunto \& Suhardjono, 2010. Penelitian tindakan. Yogyakarta: Aditya Media.

Arikunto, Suhardjono \& SUpardi, 2012. Penelitian tindakan kelas. Jakarta: PT. Bumi Aksara.

Deci, Koestner \& Ryan, 2001. Extrinsic rewards and intrinsic motivation in education: Reconsidered once again. Review of Educational Research, 71(1), pp. 1-27.

Eskasasnanda \& Purnomo, A., 2018. Knowledge sharing motivation and benefits in Faculty of Social Sciences Lesson Study Community (KLS) Universitas Negeri Malang, Malang: Universitas Muhammadiyah Malang.

Green, 2002. Using an expectancy-value approach to examine teachers' motivational strategies. Teaching and Teacher Education, 18(8), pp. 989-1005.

Harminingsih, 2015. Penerapan model make a match untuk meningkatkan motivasi dan hasil belajar Sosiologi materi dinamika kelompok sosial. Indonesian Journal of Education and Learning, 1(1), pp. 26-34.

Lepper \& Drake, 1996. Intrinsic motivation and extrinsic rewards: A commentary on cameron and pierce's meta-analysis. Review of Educational Research, 66(1), pp. 5-32.

Pintrich \& Schunk, 1996. Motivation in education: Theory, research and applications. Englewood Cliffs: Prentice Hall.

Stipek, 2002. Motivation to learn: Integrating theory and practice. 4th ed penyunt. Boston: Allyn and Bacon.

Sutarniyati, P., 2016. Peningkatan motivasi belajar siswa menggunakan model make a match pada pelajaran IPA kelas V, Yogyakarta: Universitas Negeri Yogyakarta.

Suwarsih, M., 2007. Langkah mudah penelitian tindakan kelas. Bandung: CV. Alfabeta.

Widyaningrum, I., 2015. Peningkatan motivasi belajar IPS menggunakan metode make a match pada siswa kelas Va Sd Negeri Golo Yogyakarta, Yogyakarta: Universitas Negeri Yogyakarta.

Wigfield \& Eccles, 2000. Expectancy-value theory of achievement motivation. Contemporary Educational Psychology, 25(1), pp. 68-81.

Xiang, McBride \& SOlomon, 2003. Motivational climates in ten teachers' elementary physical education classes: An achievement goal theory approach. The Elementary School Journal, 104(1), pp. 71-92. 